$\underline{\text { articles }}$

\title{
The Effect of External Variables on Mobile Accounting App Adoption by Student Entrepreneurs
}

\author{
Muamar Nur Kholid ${ }^{1}$ a, Naziatul Asri ${ }^{1}$ b \\ 1 Department of Accounting, Faculty of Business and Economics, Universitas Islam Indonesia \\ Keywords: mobile accounting app, relative advantage, subjective norm, technology acceptance model \\ https://doi.org/10.53703/001c.29816
}

\section{Journal of Small Business Strategy}

Vol. 31, Issue 5, 2021

\begin{abstract}
The objective of this research is to investigate the effect of relative advantage and subjective norm as external variables on the technology acceptance model (TAM) to comprehend student entrepreneurs' intention to adopt a mobile accounting app. Previous research associated with the adoption of computerized or information technology-based accounting has not examined the effect of external variables and the adoption of mobile accounting app. Student entrepreneurs who possessed micro and small enterprise can be potential market targets because they are categorized as $\mathrm{Y}$ and $\mathrm{Z}$ generations who are tremendously familiar with smartphone-based technology. This research administered a questionnaire and involved 191 student entrepreneurs who own a business categorized as micro and small enterprises. The data were analyzed employing Partial Least

Square-Structural Equation Model (PLS-SEM). The result of the analysis revealed that this research model is able to elaborate $57.5 \%$ of student entrepreneurs' intention to adopt a mobile accounting app. The result of the research presents that relative advantage has a positive effect on perceived ease of use (PEOU) and perceived usefulness (PU). Meanwhile, the subjective norm possesses a positive effect on PEoU, in which PEoU is a major predictor of the intention. The result of this research provides additional insight into strategies to increase the utilization of mobile accounting app by student entrepreneurs.
\end{abstract}

\section{Introduction}

A mobile accounting app is established as one of the means performed by some parties to support micro and small entities in Indonesia to record transactions and produce a financial report (Zulaikha, 2017). It is an application embedded in a smartphone. The app is developed with the rationale of the large number of micro and small enterprises in Indonesia which are not able to access capital and banking because they cannot record the transactions and produce a financial report (Mahrizal, 2017). Bank Indonesia is one of the parties which enhance a mobile accounting app. Cooperating with the Institute of Indonesia Chartered Accountants (IAI), the Central Bank of Indonesia developed a mobile accounting app named SIAPIK (Bank Indonesia \& Ikatan Akuntan Indonesia, 2016). Some other private companies in Indonesia have also recrudesced the mobile accounting app, comprising of Akuntansi UKM, Teman Bisnis, Buku Warung, and others. However, compared with the number of micro and small enterprises in Indonesia, the degree of mobile accounting app adoption by micro and small enterprises in Indonesia is still considered as low (Kholid et al., 2020). Regarding this issue, it is crucial to understand the factors influencing micro and small enterprises in Indonesia to adopt a mobile accounting app.

Research associated with the adoption of computerized accounting system in Malaysia discovered that variables in technology acceptance model (TAM) which covers Perceived Usefulness (PU) and Perceived Ease of Use (PEoU) significantly influences intention to adopt computerized accounting system (Fazli et al., 2012). The other researches about the adoption of an online accounting system in the USA also unveiled that TAM is able to explain the intention of the adoption of an online accounting system (Greenberg et al., 2012). Furthermore, research about the adoption of a computerized accounting system in public sectors in Malaysia also identified that PU and PEoU had an effect on the intention to adopt a computerized accounting system (Ilias, 2013). Moreover, research in Bangladesh presents that TAM can also explain the intention to adopt the accounting information business (Amin et al., 2016). The findings of the mentioned researches confirm that TAM has been able to

\footnotetext{
a Corresponding Author

Jl. Prawiro Kuat, Ngringin, Condongcatur, Depok, Sleman, Daerah Istimewa Yogyakarta 55283, Indonesia, muamar.nk@uii.ac.id

b Jl. Prawiro Kuat, Ngringin, Condongcatur, Depok, Sleman, Daerah Istimewa Yogyakarta 55283, Indonesia, naziatul14@gmail.com
} 
be validated and considered as a robust theory to elaborate the adoption of transaction records based on information technology. Nevertheless, TAM does not thoroughly involve all elements affecting the intention to adopt and actual usage of information technology (Mutahar et al., 2018). The original TAM suggests companies to determine the effect of external variables on the main construct of TAM, which is PU and PEoU (Davis, 1989). Previous researches about the adoption of technology-based accounting have not calculated the influence of external variables on the prior construct of TAM (Amin et al., 2016; Basioudis et al., 2012; Fazli et al., 2012; Greenberg et al., 2012). Regarding this issue, this research attempt to occupy the gap discovered in previous research by examining the effect of external variables (subjective norm and relative advantage) on PU and PEoU.

Previous research has evident that users' intention to adopt information technology can be explained by TAM and the Theory of Planned Behavior. However, the research conducting the effect of subjective norm on the main construct of TAM displays inconsistent results. The research by Jin (2014), Teo (2010), as well as Yuen \& Ma (2008) discovered the effect of subjective norm on the main construct of TAM. Meanwhile, other prior research did not unveil the effect of subjective norm on PU, but they identified the effect of subjective norm on PeoU (Abdullah et al., 2016; Peregrina et al., 2014). The individual differences and the different contexts of technology which become the research objects and one of the contingent factors are some causes of it (Schepers \& Wetzels, 2007).

As part of the diffusions of innovation theory, the relative advantage is a crucial factor affecting users to determine to adopt information technology (Jin, 2014; Sang et al., 2009). Relative advantage is the extent to which an innovation is considered to be more enormous than the ideas it substitutes (Rogers, 2003). Mobile accounting app delivers the innovation of the manual record changing to technology-based record in a smartphone. The change leads to a view that the mobile accounting app is a more tremendous innovation than the manual record, so the relative advantage is considered as one of the determinant factors to adopt a mobile accounting app. Previous research revealed the significant effect of relative advantage on the information technology adoption (Fai et al., 2018).

The difference in age of information technology users plays an essential role because it can be a crucial variable which affects the adoption of information technology (Boonsiritomachai \& Pitchayadejanant, 2017; Morris et al., 2005). For instance, in the information technology adoption, older respondents tend to be tremendously affected by perceived behavioral control, while younger respondents tend to be strongly influenced by attitude toward utilizing the technology (Morris \& Venkatesh, 2000). In accordance with the findings, this research is concentrated on student entrepreneurs categorized as $\mathrm{Y}$ and $\mathrm{Z}$ generations possessing a micro and small enterprise. The focus on the student entrepreneurs as respondents in this research is with the rationale that $\mathrm{Y}$ and $\mathrm{Z}$ generations generally discover and employ information through a smartphone. They were able to select which technology is appropriate and then learn to use it. In other words, they find it easier to do activities utilizing technology compared to older generations (Boonsirito- machai \& Pitchayadejanant, 2017). A better understanding of the age segment-in this case, student entrepreneurs-is expected to enhance mobile accounting app providers to examine appropriate strategies to attain a higher degree of mobile accounting app adoption. Ultimately, different from previous research conducted by Amin et al. (2016); Basioudis et al. (2012); Fazli et al. (2012); Greenberg et al. (2012) with the object of computerized information technology-based transaction record, this research concerned primarily on the adoption of smartphone-based accounting record. It is significantly distinguished because the research model explaining a person's behavior is limited by certain functions of the used technology (Cho, 2016).

Based on the explanation above, the objective of this research is to examine the effect of external variables (subjective norm and relative advantage) on the prior construct of TAM (PU and PEoU) in the mobile accounting app adoption context by student entrepreneurs. In the next section, the literature review and the explanation of hypotheses development are provided. In the third section, the methodology implemented in this research encompassing data collection, instrument development, and data analysis is discussed. The fourth section demonstrates the data analysis results. Next, the fifth section provides discussions. In the sixth section, the managerial implication is described. Subsequently, the last section provides conclusion of the research.

\section{Literature Review \\ Mobile Accounting App}

The mobile accounting app is a financial transaction record application installed in a smartphone and is able to be employed in performing accounting functions-recording business transactions and producing financial reports (Tribunella \& Tribunella, 2016). It eases micro and small enterprises to store financial transactions and produce financial reports even though it does not own broad knowledge about financial accounting. In Indonesia, mobile accounting app providers are from some parties, both government and private sectors. Some mobile accounting apps in Indonesia consist of Sistem Informasi Aplikasi Pencatatan Informasi Keuangan (SIAPIK), Jurnal Mobile, Akuntansi UKM-Money Manager, Teman Bisnis, and others. Although there are various mobile accounting app providers in Indonesia, most of them are merely compatible with Android. They are provided for both free and paid services.

Generally, the mobile accounting app provides users with some advantages. First, it can be utilized for some types of businesses like trading, service, or manufacture. Second, transaction data in the mobile accounting app are backedup if the user changes their smartphone. Third, users are able to store transactions at anytime and anywhere as long as they employ the smartphone installed with the application. Lastly, users do not require to upgrade mobile accounting app software because the providers automatically update it regularly.

\section{Technology Acceptance Model (TAM)}

TAM is a useful model which is able to explain users' be- 
haviors toward the adoption of information technology. It is optimized by Davis (1989) proposing the theory of reasoned action (TRA) developed by Fishbein \& Ajzen (1975) as its basic theory. PU and PEoU are applicable beliefs which become the primary variable leading users to adopt information technology and are affected by external variables (Davis, 1989). Figure 1 illustrates the original TAM developed by Davis (1989). The original TAM encompasses attitude as a determinant factor of intention to adopt information technology. However, this research does not include attitude in explaining intention to adopt mobile accounting app because it does not significantly influence between constructs (Abdullah et al., 2016; Bhatiasevi, 2016; Mutahar et al., 2018).

PU is defined as a degree to which a person believes that their job performance can be improved by administering information technology (Davis, 1989). TAM states that PU is an essential antecedent affecting users' intention to adopt information technology (Davis, 1989). In the context of the mobile accounting app, it implies that the degree of belief of student entrepreneurs on how mobile accounting apps enhance their job performance affects whether they utilize mobile accounting or not. Previous research revealed a positive effect of PU on the intention to adopt information technology such as the adoption of learning management system (Yalcin \& Kutlu, 2019), mobile banking (Mutahar et al., 2018), crowd-funding (Thaker et al., 2018), online accounting system (Fazli et al., 2012; Greenberg et al., 2012; Ilias, 2013), mobile library application (Rafique et al., 2020), and financial technology (Shaikh et al., 2020). Based on those explanations, the following hypothesis is proposed.

H1: Perceived usefulness possesses a positive effect on the intention to adopt mobile accounting app.

PEoU is explained as a degree by which a person believes that employing information technology is free of effort (Davis, 1989). An individual who believes that learning and utilizing new things with the newest information technology are easy owns a higher intention to employ it (Davis, 1989). In the context of this research, student entrepreneurs will possess a strong intention to adopt mobile accounting app if they believe that learning to implement and using a mobile accounting app is easy. Research in the context of mobile technology also discovered a positive effect of PEoU on the intention to adopt mobile library application (Rafique et al., 2020), mobile learning system (Almaiah \& Alismaiel, 2019), machine translation (Yang \& Wang, 2019), and mobile banking (Mutahar et al., 2018). Therefore, the following hypothesis is established.

H2: Perceived ease of use has a positive effect on the intention to adopt mobile accounting app.

TAM elaborates that a person's PU on the newest information technology is influenced by the subjective perception of easiness to employ the technology (Davis, 1989). Empirical examinations from previous research confirmed the effect of PEoU on PU (Bashir \& Madhavaiah, 2015; Hassan \& Wood, 2020; Mutahar et al., 2018; Rafique et al., 2020; Reynolds et al., 2020; Wang et al., 2020; Yoon, 2016; Youn \& Lee, 2019). Thus, in the context of the mobile accounting app, it is hypothesized that the more robust the student entrepreneurs' belief that utilizing a mobile accounting app is easy, the stronger the belief that mobile ac-

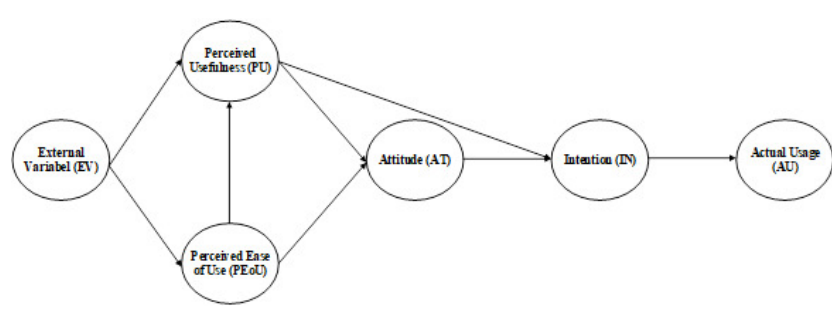

Figure 1. Original TAM (Davis, 1989)

counting app is useful. Hence, the following hypothesis is implemented.

H3: Perceived ease of use possesses a positive effect on the perceived usefulness.

\section{Subjective Norm}

TAM owns a crucial contribution to the understanding of the behavior of utilizing and accepting information technology. However, requiring to be completed as the social influence is not considered yet (Malhotra \& Galletta, 1999). Hence, Venkatesh \& Davis (2000) encompassed subjective norm which was a social variable into TAM. Subjective norm is perceived as the proportion to which an individual believes and performs certain activities according to what their important others conduct (Fishbein \& Ajzen, 1975). In this research context, the subjective norm is a perception that the important others think they should or should not adopt a mobile accounting app.

Subjective norm influences PU to adopt information technology (Venkatesh \& Davis, 2000). When important others think that the individual demands to employ information technology, the individual perceives information technology useful (Yuen \& Ma, 2008). Some studies about subjective norm revealed that important others are able to affect a person's decision to adopt information technology. The results of meta-analysis also present that 22 of 24 articles find subjective norm possesses a significant effect on PU (Schepers \& Wetzels, 2007). Some research which has unveiled the effect of subjective norm on PU is the adoption of an e-book (Jin, 2014; Salloum \& Shaalan, 2019), computer (Teo, 2010), e-portfolios (Abdullah et al., 2016), and e-learning (Yuen \& Ma, 2008). Therefore, the following hypothesis is declared.

H4: Subjective norm has a positive effect on perceived usefulness.

Although the analyses of subjective norm toward PEoU are not as many as the analyses of subjective norm toward PU, some studies uncovered that subjective norm possesses a tremendous effect on PEoU. When important others think that an individual requires to utilize information technology, the individual thinks that administering information technology is easy (Yuen \& Ma, 2008). The results of metaanalysis also present that $66.67 \%$ of articles revealed a significant effect of subjective norm on PEoU (Schepers \& Wetzels, 2007). Some research about the adoption of elearning (Yuen \& Ma, 2008), e-portfolios (Abdullah et al., 2016), e-book (Jin, 2014; Salloum \& Shaalan, 2019), and free voluntary service (Watjatrakul, 2013) unveiled a positive effect of subjective norm on PEoU. Based on those ex- 
planations, the following hypothesis is designed.

H5: Subjective norm has a positive effect on perceived ease of use

\section{Relative Advantage}

The diffusion of innovations (DOI) theory illustrates how innovation diffuses to the society (Rogers, 2003). Innovation is defined as a practice or idea perceived as a new thing by individuals, while diffusion is a process in which innovation is communicated through some channels from time to time between the social system members (Rogers, 2003). Five attributes influencing the rate diffusion of innovations are relative advantage, compatibility, complexity, trialability, and observability (Rogers, 2003). In the context of information technology adoption, some previous research discovered that relative advantage, compatibility, and complexity possess a more crucial role than do the others (Carter \& Bélanger, 2005). However, complexity is frequently considered to possess similarities with PEoU (Yuen et al., 2020) and relative advantage owns a more tremendous effect than does the compatibility (Sang et al., 2009). Therefore, this research merely encompasses relative advantage as the external variable influencing TAM.

Relative advantage is closely associated with user adaptation and displays a significant positive correlation with the adaptation of information technology (Fai et al., 2018; Jin, 2014). A technology-based mobile accounting app is defined to possess better advantages than the manual accounting record. By utilizing a mobile accounting app, student entrepreneurs do not require to depend manually administering a calculator because the counting is conducted automatically by the system. They do not need to understand the complexity of the accounting cycle and process because it is also automatically enacted by the system (Andriawan, 2019; Utami, 2018). When student entrepreneurs perceive mobile accounting app possesses better advantages than the manual record, they believe that mobile accounting app is useful because it improves their job performance. Furthermore, innovations embedded in the mobile accounting app enhance the belief that employing a mobile accounting app is easier than recording manually which requires high accuracy. Previous research has uncovered a positive effect of relative advantage on PU and PEoU (Gangwar et al., 2015; Izuagbe et al., 2016; Jin, 2014; Min et al., 2018; Wu et al., 2010). Based on those explanations, the following hypotheses are proposed.

H6: Relative advantage owns a positive effect on perceived usefulness.

H7: Relative advantage owns a positive effect on perceived ease of use.

Figure 2 displays a research model of mobile accounting app based on TAM with the external variables of subjective norm and relative advantage.

\section{Research Method}

\section{Data Collection}

Participants in this research were student entrepreneurs who were pursuing undergraduate degree in universities in Yogyakarta and their enterprises were categorized as mi-

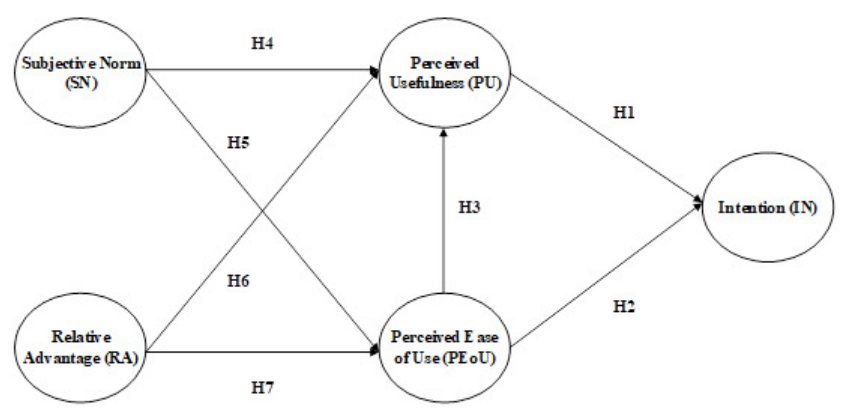

Figure 2. Proposed Research Model

cro and small enterprises. Moreover, they understand the mobile accounting app. In Indonesia enterprises are categorized micro if they possess turnover less than IDR 300 million in one year and are categorized small if they have more than IDR 300 million but less than IDR 2.5 billion in one year (Indonesian Government, 2008). Yogyakarta was selected as the sample due to several reasons. First, universities in Yogyakarta possess a great business school. Faculty of Economics and Business at Universitas Gadjah Mada located in Yogyakarta is the first business school in Indonesia obtaining the accreditation from Association to Advance Collegiate Schools of Business (AACSB) (Universitas Gadjah Mada, 2014). Other business schools in Yogyakarta have also become a part of the global networks. Some of the networks include Association of Chartered Certified Accountants (ACCA) (Faculty of Business and Economics UII, 2016), and ASEAN University Network on Higher Education for Quality Assurance (AUN-QA) (Universitas Islam Indonesia, 2019; Universitas Muhammadiyah Yogyakarta, 2019). It implies that the role and existence of business schools in Yogyakarta and in global world cannot be avoided. Furthermore, Yogyakarta is also well-admitted as city of students which become higher education icon in Indonesia, in which many students from various cities in Indonesia pursue business study in Yogyakarta (Ramdhani et al., 2012).

A combination of convenience and snowball sampling techniques were employed to obtain respondents. Technically, the procedures are as follows. Potential participants who understand the mobile accounting app were selected based on the convenience sampling technique and were contacted personally. Then, they were informed the objectives and objectives of the survey. Next, they were demanded to fill in the research questionnaire. At the end of the survey, participants were demanded to recommend their colleagues who operates a mobile accounting app. The number of samples in this research was determined based on the theory which explains research investigating factor analysis requires responses as many as five times or ten times greater than the total items (Hair et al., 2007). By considering this requirement, this research required at least $105(21 \times 5)$ respondents and maximally $210(21 \times 10)$ respondents.

\section{Development of the Instrument}

This research employs a survey method utilizing questionnaires to obtain data. The questionnaire was formu- 
lated in Indonesian language. This research adopted TAM scales (Bashir \& Madhavaiah, 2015; Davis, 1989; Schierz et al., 2010; Siyal \& Ding, 2019). Meanwhile, the relative advantage was examined employing 4 items adopted from Jin (2014) and the subjective norm was calculated using 4 items adopted from Ajzen (1991) with some adjustment based on the mobile accounting app. The complete measurement items for each construct can be observed in Table 2 .

This research administered a 6-point Likert scale from 'strongly disagree' to 'strongly agree'. This research employed even Likert scale as proposed by Matell \& Jacoby (1972) to avoid central tendency error by respondents. Central tendency error occurs when respondents select the middle answer (neutral) (Rahman, 2015). Several research in the context of the information adoption technology also utilized even Likert scale, such as Izauagbe et al., (2016); Rahman, (2015); Urumsah, (2015).

\section{Data Analysis}

Data analysis in this research was performed the partial least square - structural equation model (PLS-SEM) enhanced by SmartPLS 3.0 software. The analysis was enacted in two stages, which were measurement model and structural model analysis (Hair et al., 2017). The measurement model analysis encompassed the convergent validity test, internal consistency test, and discriminant validity test. Meanwhile, the structural model analysis included the significance and relevance of the structural model relationships, examined the degree of $\mathrm{R}^{2}$, and assessed the predictive relevance $\mathrm{Q}^{2}$ (Hair et al., 2017).

\section{Sample Profile}

This research involved 191 student entrepreneurs in total. The number of samples is in accordance with a theory coined by Hair et al. (2007). Perceived from gender, the number of female respondents $(73.3 \%)$ more enormous than that of male respondents (26.7\%). Viewed from age, the majority of respondents are $21+$ to 22 years old (40.3\%) and $22+$ to 23 years old (22.5\%). All respondents (100\%) were pursuing an undergraduate degree and can be described as Accounting and Business students (66.5\%) and Non-Accounting and Business students (33.5\%). Related to the entity possessed by respondents, the majority of their enterprise is less than 1 year (45.0\%) and owns a turnover less than 100 million rupiahs per year (59.7\%). Table 1 displays detail sample profile.

\section{Measurement Model Assessment}

The evaluation of convergent validity includes the test of average variance extracted (AVE) and an outer loading indicator. The result of the analysis presents that all indicators from constructs possess an outer loading value above 0.7. It displays that construct items fulfill the outer loading test (Hair et al., 2017). For instance, the SN1 construct possesses a loading value of 0.866 which is above 0.7 . Perceived from AVE value, all constructs in this research own value above 0.5 . It displays that constructs in this research have fulfilled the convergent validity test (Hair et al., 2017). For example, the relative advantage construct owns AVE value 0.834 which is far above 0.5 . The result of reliability analysis can be identified from Cronbach's Alpha (CA) value or Composite Reliability (CR) value. If the CA value or CR value is above 0.7 , it is implied that the construct has fulfilled the reliability test (Hair et al., 2017). The result of the analysis illustrates that the CA value and CR value from each construct is above 0.7 . For instance, there is a PU construct with CA value 0.961 and CR value 0.971 . Table 2 displays a complete result of convergent validity and reliability tests.

The next measurement model is associated with discriminant validity which is examined employing the FornellLarcker criteria by comparing AVE square root of each construct with the correlation between constructs (Hair et al., 2017). As described in Table 3, the AVE square root of each construct is higher than the highest correlation of construct with any other construct embedded in the model. It indicates that the discriminant validity test is fulfilled.

\section{Structural Model and Hypothesis Testing}

Figure 3 displays the result of the structural model and hypothesis tests. The result presents that this research model demonstrates the variance of student entrepreneurs' intention to utilize the mobile accounting app as much as $\mathrm{R}^{2}=57.5 \%$. The value displays that this research model describes the intention to adopt a mobile accounting app included in the moderate category because it is above $50 \%$ and under 75\% (Hair et al., 2017). Meanwhile, relative advantage, subjective norm, and PEoU illustrate the variance of $\mathrm{PU}$ as much as $\mathrm{R}^{2}=70.9 \%$. The value implies that the model explaining PU is also encompassed in the moderate category. In accordance with the PEoU, the value of $\mathrm{R}^{2}$ is $47.3 \%$. It displays that the model is included in the weak category because it is under 50\% (Hair et al., 2017). Besides analyzing the coefficient of determination $\left(\mathrm{R}^{2}\right)$, this research also examined predictive relevance $\left(\mathrm{Q}^{2}\right)$. Predictive relevance in this research was performed by observing Stone-Geisser's $\mathrm{Q}^{2}$ value to understand the degree of predictive relevance from the exogenous variable (Hair et al., 2017). The result of the analysis presents that the endogenous variable in this research covering intention $\left(\mathrm{Q}^{2}=0.474\right), \mathrm{PU}\left(\mathrm{Q}^{2}=0.627\right)$, and PEoU $\left(\mathrm{Q}^{2}=0.413\right)$ possesses $\mathrm{Q}^{2}$ value above 0 . It can be implied that exogenous variable in this research owns predictive relevance toward endogenous variable.

The analysis of PLS-SEM revealed that PU owns a significant positive effect on the intention to adopt a mobile accounting app ( $\beta=0.312 ; p<0.01$ ), so H1 is supported. H2 and $\mathrm{H} 3$ are upheld because $\mathrm{PEoU}$ possesses a significant positive effect on the intention $(\beta=0.485 ; p<0.01)$ and $\mathrm{PU}(\beta=0.654$; $p<0.01)$. The result of the analysis presents that subjective norm owns no significant effect on PU ( $\beta=-0.061$; not significance), but it possesses a significant positive effect on PEoU ( $\beta=0.395 ; p<0.01)$. It indicates that $\mathrm{H} 4$ is rejected and $\mathrm{H} 5$ is supported. In accordance with the relative advantage, the result of the analysis presents that relative advantage has a significant positive effect on PU $(\beta=0.309 ; p<0.01)$ and PEoU $(\beta=0.484 ; p<0.01)$. It indicates that $\mathrm{H} 6$ and $\mathrm{H} 7$ 
Table 1. Descriptive respondents and the entity

\begin{tabular}{|c|c|c|c|}
\hline Variable & Description & Numbers & Percentage \\
\hline \multirow[t]{2}{*}{ Gender } & Male & 51 & $26.7 \%$ \\
\hline & Female & 140 & $73.3 \%$ \\
\hline \multirow{7}{*}{ Age } & $18+\mathrm{s} / \mathrm{d} 19$ years old & 4 & $2.1 \%$ \\
\hline & $19+\mathrm{s} / \mathrm{d} 20$ years old & 9 & $4.7 \%$ \\
\hline & $20+s / d 21$ years old & 31 & $16.2 \%$ \\
\hline & $21+\mathrm{s} / \mathrm{d} 22$ years old & 77 & $40.3 \%$ \\
\hline & $22+\mathrm{s} / \mathrm{d} 23$ years old & 43 & $22.5 \%$ \\
\hline & $23+s / d 24$ years old & 8 & $4.2 \%$ \\
\hline & $24+s / d 25$ years old & 19 & $9.9 \%$ \\
\hline \multirow{2}{*}{ Study Program } & Accounting and business & 127 & $66.5 \%$ \\
\hline & Non-Accounting and business & 64 & $33.5 \%$ \\
\hline \multirow{5}{*}{ Enterprise age } & $<1$ years & 86 & $45.0 \%$ \\
\hline & 1 - 2 years & 64 & $33.5 \%$ \\
\hline & $3-4$ years & 22 & $11.5 \%$ \\
\hline & 5 - 6 years & 11 & $5.8 \%$ \\
\hline & $>10$ years & 8 & $4.2 \%$ \\
\hline \multirow{11}{*}{ Turnover/year } & $<$ IDR 100.000 .000 & 114 & $59.7 \%$ \\
\hline & IDR100.000.000 - 200.000.000 & 17 & $8.9 \%$ \\
\hline & IDR 200.000.000 - 300.000.000 & 3 & $1.6 \%$ \\
\hline & IDR 300.000.000 - 400.000.000 & 7 & $3.7 \%$ \\
\hline & IDR 400.000.000 - 500.000.000 & 8 & $4.2 \%$ \\
\hline & IDR 500.000.000 - 600.000.000 & 8 & $4.2 \%$ \\
\hline & IDR 600.000.000 - 700.000.000 & 9 & $4.7 \%$ \\
\hline & IDR 700.000.000 - 1.000.000.000 & 9 & $4.7 \%$ \\
\hline & IDR900.000.000 - 1.000.000.000 & 6 & $3.1 \%$ \\
\hline & IDR 800.000.000 - 900.000.000 & 5 & $2.6 \%$ \\
\hline & IDR1.000.000.000 - 1.300.000.000 & 5 & $2.6 \%$ \\
\hline
\end{tabular}

are approved.

\section{Discussion}

The prior objectives of this research are to examine the external variables such as subjective norm and relative advantage towards the main construct of TAM (PU and PEoU) and to identify the effect of PU and PEoU on student entrepreneurs' intention to adopt mobile accounting app to record transactions. Based on the data analysis, generally, it is discovered that hypotheses proposed are enhanced. This research revealed that TAM and external variables - subjective norm and relative advantage - play an essential role in elaborating student entrepreneurs' intention to use mobile accounting app.

From the 7 hypotheses, 6 of them are supported and 1 is rejected $(\mathrm{H} 4)$. The result of the hypotheses test indicates that relative advantage owns a positive effect on PEoU. It implies that the bigger the perception of student entrepreneurs about relative advantage, the higher the perception that utilizing a mobile accounting app is easy. The important role of relative advantage on PEoU is also discovered in research conducted by Gangwar et al. (2015) and Yuen et al.

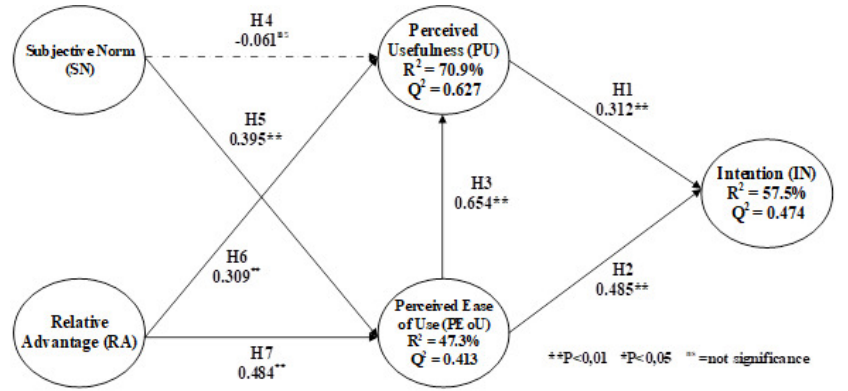

Figure 3. Results of Hypothesis Testing, Coefficient of Determination $\left(R^{2}\right)$ \& Predictive Relevance $\left(Q^{2}\right)$

(2020). Moreover, the result of the analysis uncovered that PU increases when respondents have a high relative advantage. Research about the adoption of an e-book (Jin, 2014), adoption of cloud computing, adoption of Electronic Information Resources (Izuagbe et al., 2016), and adoption of autonomous vehicle (Yuen et al., 2020) also unveiled the positive effect of relative advantage on PU. Relative advantage possesses a more important role in PEoU than on PU. It is in 
Table 2. Measurement Model Assessment: Convergent Validity \& Reliability

\begin{tabular}{|c|c|c|c|c|}
\hline Items & Loading & AVE & CA & CR \\
\hline Subjective Norm (SN) & & 0.814 & 0.924 & 0.946 \\
\hline Majority of entrepreneurs I know utilize mobile accounting app (SN1) & 0.866 & & & \\
\hline My important others employ mobile accounting app (SN2) & 0.915 & & & \\
\hline Majority of people I know agree if I utilize mobile accounting app (SN3) & 0.893 & & & \\
\hline $\begin{array}{l}\text { Majority of people I know assume that I need to employ a mobile accounting app } \\
\text { (SN4) }\end{array}$ & 0.933 & & & \\
\hline Relative Advantage (RA) & & 0.834 & 0.933 & 0.952 \\
\hline $\begin{array}{l}\text { Generally, mobile accounting app is better than manual transaction recording } \\
\text { (RA1) }\end{array}$ & 0.872 & & & \\
\hline $\begin{array}{l}\text { To use mobile accounting app possesses more positive effect than to record } \\
\text { transactions manually (RA2) }\end{array}$ & 0.921 & & & \\
\hline Mobile accounting app is more efficient than manual transaction recording (RA3) & 0.916 & & & \\
\hline Mobile accounting app is more helpful than manual transaction recording (RA4) & 0.942 & & & \\
\hline Perceived Usefulness (PU) & & 0.894 & 0.961 & 0.971 \\
\hline By utilizing mobile accounting app, transaction recording becomes faster (PU1) & 0.932 & & & \\
\hline $\begin{array}{l}\text { By operating mobile accounting app, transaction recording can be performed more } \\
\text { efficient (PU2) }\end{array}$ & 0.943 & & & \\
\hline Mobile accounting app is useful for transaction recording (PU3) & 0.952 & & & \\
\hline Mobile accounting app appears to be practical (PU4) & 0.956 & & & \\
\hline Perceived Ease of Use (PEoU) & & 0.893 & 0.970 & 0.977 \\
\hline Mobile accounting app is easy to use (PEoU1) & 0.943 & & & \\
\hline Mobile accounting app is easy to learn (PEoU2) & 0.949 & & & \\
\hline $\begin{array}{l}\text { Instructions to utilize mobile accounting app is easy to understand and clear } \\
\text { (PEoU3) }\end{array}$ & 0.956 & & & \\
\hline It is easy to remember how to employ a mobile accounting app (PEoU4) & 0.940 & & & \\
\hline Generally, utilizing a mobile accounting app is easy (PEoU5) & 0.937 & & & \\
\hline Behavioral Intention (IN) & & 0.844 & 0.938 & 0.956 \\
\hline I will utilize a mobile accounting app for transaction recording (IN1) & 0.927 & & & \\
\hline I will employ a mobile accounting app in the near future (IN2) & 0.940 & & & \\
\hline I readily use mobile accounting app in the near future (IN3) & 0.901 & & & \\
\hline I intend to utilize a mobile accounting app (IN4) & 0.905 & & & \\
\hline
\end{tabular}

Table 3. Measurement Model Assessment: Discriminant Validity

\begin{tabular}{llllll}
\hline & IN & PEoU & PU & RA & SN \\
\hline IN & 0.918 & & & & \\
PEU & 0.734 & 0.945 & & & \\
PU & 0.700 & 0.799 & 0.946 & & 0.913 \\
RA & 0.542 & 0.566 & 0.667 & 0.207 & 0.902 \\
SN & 0.539 & 0.499 & 0.329 & & \\
\hline
\end{tabular}

Note: Diagonal terms (in italic) are the square roots of the AVE

accordance with the research by Gangwar et al. (2015) which revealed a bigger effect of relative advantage on PEoU than PU, but it is not supported by the research conducted by Jin (2014).

A significant positive effect of subjective norm on PEoU informs that student entrepreneurs' belief that employing mobile accounting app is easy is influenced by their important others (lecturers, friends, or family). When important others believe that they should employ a mobile accounting app, student entrepreneurs tend to possess a belief that utilizing a mobile accounting app is effortless. It is in accordance with the previous research (Abdullah et al., 2016; Jin, 
2014; Salloum \& Shaalan, 2019). An interesting result can be observed from the test of $\mathrm{H} 4$ in which subjective norm owns no significant effect on PU. It indicates that the degree of student entrepreneurs' PU is not influenced by their peers. This result is supporting the research by Abdullah et al. (2016) in the context of e-portfolios adoption which also revealed that the subjective norm has no significant effect on PU. However, this finding proves that the effect of subjective norm on PU is indirect and is mediated by PEoU. It is strengthened by a finding which displays the subjective norm in the adoption of mobile accounting app and possesses a greated role on PEoU than on PU. This result is in accordance with previous research (Min et al., 2018; Watjatrakul, 2013). It happens because the majority of the samples in this research are Accounting and Business students in which their surroundings are people who comprehend transaction recording and also understand some mobile accounting app providers. Some brands have similar functions, thus, the influence of peers tends to percieve the easiness of utilizing a mobile accounting app than the usefulness of it.

Both PEoU and PU predict the intention to use information technology. This research also approves that PEoU owns a significant positive effect on PU. It means that student entrepreneurs who believe that utilizing a mobile accounting app is easy possess more robust trust that the mobile accounting app is useful. It is consistent with some previous research which discovered a significant effect of PEoU on PU (Hassan \& Wood, 2020; Rafique et al., 2020; Reynolds et al., 2020; Wang et al., 2020; Youn \& Lee, 2019). Student entrepreneurs perceive that the mobile accounting app is easy and useful. Thus, they have a stronger intention to employ or adopt it. This result upholds previous research (Rafique et al., 2020; Shaikh et al., 2020; Thaker et al., 2018) that empirically revealed the effect of PEoU and PU on the intention to adopt some contexts of information technology.

\section{Managerial Implication}

The result of this research proposes student entrepreneurs, mobile accounting app providers (government or private sectors), and university information some significant factors influencing student entrepreneurs to utilize mobile accounting app. When developing a mobile accounting app, providers should be able to predict whether the app being established is accepted by users. They also require investigating why users do not accept the mobile accounting app. Therefore, they have to conduct a necessary action to increase the adoption of mobile accounting app.

The result of this research uncovered that PEoU is the key factor for student entrepreneurs to adopt mobile accounting app and for PU. Therefore, mobile accounting app providers are demanded to develop a user-friendly app. Student entrepreneur are potential targets for the market of mobile accounting app because most of them are $\mathrm{Y}$ and $\mathrm{Z}$ generations who are tremendously familiar with smartphone-based technology. Associated with this matter, mobile accounting app providers may cooperate with universities to provide sufficient information about the mobile accounting app. Furthermore, it is relevant to design and provide training regarding the utilization of permanent and sustainable Information and Communication Technologies (ICT) as well as the implementation in the context of higher education (Melo et al., 2020). Providers are able to cooperate with universities to train students to employ mobile accounting app and also to provide personal support to students to be able to operate a mobile accounting app. Moreover, providers are required to utilize social media like YouTube by creating a tutorial video on how to implement a mobile accounting app to increase PEoU. Perceived from the perspective of student entrepreneurs as the business owner, they are required to foster self-belief or their employees' belief that operating mobile accounting app is easy, so they and their employees possess an intention to utilize it. To acquire this achievement, student entrepreneurs must be able to select which mobile accounting app can support them and their employees. For instance, there is an apparent manual in the form of a book or video. Moreover, the provider facilitates 24 hours service if there comes a problem, provides intensive training, etc.

This research also unveiled that PU possesses a significant positive effect on the intention to adopt a mobile accounting app. Therefore, mobile accounting app providers should produce some services which can be performed utilizing the app. Mobile accounting app is expected not only to support transaction recording and financial reports based on International Financial Reporting Standard (IFRS) but also to provide other features such as a reminder about receivable and payable meeting deadlines, chart-based analysis about the fluctuation of revenue, profit, expense, and etc. The more the service provided, the more belief student entrepreneurs possess that utilizing mobile accounting app is useful. Meanwhile, student entrepreneurs require to be aware of the services provided by the mobile accounting app. Therefore, they are demanded to select which app is the most useful and appropriate for their business characteristics.

Based on the finding, relative advantage possesses a significant positive effect on PEoU and PU, mobile accounting app providers are necessitated to be able to increase the perception of relative advantage by noticing differences between mobile accounting app and manual transaction recording. Mobile accounting app possesses more advantages than the manual transaction recording, such as supporting users to save time and energy, managing payable and receivable in a better way, minimizing the risk of transaction recording mistakes, and organizing transaction data (Utami, 2018). Providers are also expected to communicate the advantages of mobile accounting app intensively to increase PEoU and PU. Hence, student entrepreneurs can possess a stronger intention to utilize the app.

Subjective norm is a significant predictor to increase student entrepreneurs' perception of how easy a mobile accounting app is to employ. Providers are required to build strategies which affect important others such as lecturers, friends, or family. Thus, they are able to support student entrepreneurs to perceive that mobile accounting app is easy and increases the intention to adopt it. Marketing strategy of higher education institutions can be one of the best choices because higher education institutions in Indonesia are required by the government to possess a business in- 
cubator which involves student entrepreneurs as the main subject (Sindo, 2018). It leads lecturers to become a crucial factor influencing student entrepreneurs' business decisions. Providers' ability to provide sufficient information to lecturers affects lecturers' ability to influence student entrepreneurs to adopt mobile accounting app. Perceived from student entrepreneurs, this result presents knowledge that there are some types of mobile accounting app. They can select which apps employed by the people around them (lecturers or business partners) so that they can receive support from those people if they notice any difficulties in using the app. When they find it easy to solve the problems, they will own a high PEoU degree which increases the intention to adopt a mobile accounting app.

In general, the result of this research also provides implications to universities as a party which is able to influence the growth of student entrepreneurs' business. Referring to the significant role of the subjective norm in the adoption of mobile accounting app, universities, through lecturers, are required to introduce and support the use of information technology early when student entrepreneurs develop their business. A mobile accounting app which upholds transaction recording for micro and small enterprises is expected be introduced earlier. Mobile accounting app which possesses more advantages than manual transaction recording produces financial information faster and assist student entrepreneurs to perform the right business decisions. The implementation of mobile accounting app leads them to make better decisions.

Although this research focuses on student entrepreneurs' respondents, the results of this research can be implemented by entrepreneurs in general in utilizing mobile accounting app. Based on the results of this research, business owner must be able to select mobile accounting app which is not hard to be operated, provides various services, and possesses many advantages than manual transaction record. If they own accountant performing the process of transaction recording, business owner must also able to assure their accountant that the mobile accounting app they have selected is easy to employ, can fasten the transaction record, provide benefits for accountant jobs, and own many advantages than manual accounting. On the other hand, mobile accounting app providers are also demanded to arrange appropriate marketing strategy to ensure entrepreneurs to apply provided mobile accounting app. Providers should deliver information regarding the benefits for the business application, easiness of application, and various services provided in the application.

\section{Conclusion}

The primary objective of this research is to examine the influence of the external variables such as subjective norm and relative advantage towards the main construct of TAM in the context of mobile accounting app adoption by student entrepreneurs in Indonesia. Holistically, it can be concluded that PEoU is able to increase student entrepreneurs' PU and improve their intention to adopt a mobile accounting app. Furthermore, it is revealed that PU has a positive effect on the intention to adopt a mobile accounting app. Another finding associated with the external variables is that relative advantage possesses a positive effect on PU and PEoU, while subjective norm has a positive effect on PEoU, but has no significant effect on PU. As a determinant of the intention to adopt a mobile accounting app, PEoU owns a greater role than PU. As an external variable, relative advantage possesses a stronger effect on PU and PEoU than does the subjective norm. As revealed in this research, after student entrepreneurs evaluated mobile accounting app based on their perception about ease of use, usefulness, subjective norm, and relative advantage, they eventually determined to adopt a mobile accounting app or not. It indicates that the bigger their perception about the ease of use, usefulness, subjective norm, and relative advantage, the stronger their intention to adopt a mobile accounting app.

Although this research is able to describe student entrepreneurs' intention to adopt a mobile accounting app, it possesses some limitations. First, the sample is dominated by the female (73.3\%). Some studies about adopting information technology have discovered gender as an important role influencing moderation in adopting technology (Goh et al., 2014). Second, the sample of this research is dominated by student entrepreneurs pursuing Accounting and Business. Future research is expected to consider employing multi-group analysis by dividing student entrepreneurs into two, which are students from Accounting and Business and students from non-Accounting and Business majors. Hence, it is able to provide deeper knowledge related to the influence of moderation of major differences taken by student entrepreneurs. 


\section{REFERENCES}

Abdullah, F., Ward, R., \& Ahmed, E. (2016). Investigating the influence of the most commonly used external variables of TAM on students' Perceived Ease of Use (PEOU) and Perceived Usefulness (PU) of e-portfolios. Computers in Human Behavior, 63, 75-90. https://doi.org/10.1016/i.chb.2016.05.014

Ajzen, I. (1991). The Theory of Planned Behavior. Organizational Behavior and Human Decision Processes, 50(2), 179-211. https://doi.org/10.1016/074 9-5978(91)90020-T

Almaiah, M. A., \& Alismaiel, O. A. (2019). Examination of factors influencing the use of mobile learning system: An empirical study. Education and Information Technologies, 24(1), 885-909. https://do i.org/10.1007/s10639-018-9810-7

Amin, K., Munira, S., Azhar, A., Amin, A., \& Karim, M. T. (2016). Factors Affecting Employees' Behavioral Intention to Adopt Accounting Information System ( AIS ) in Bangladesh. 19th International Conference on Computer and Information Technology, 501-505.

Andriawan, F. (2019). 5 Aplikasi Akuntansi Buat Pengusaha yang Benci Pembukuan. Paper.Id. https://w ww.paper.id/blog/tips-dan-nasihat-umkm/aplikasi-ak untansi-terbaik/

Bank Indonesia, \& Ikatan Akuntan Indonesia. (2016). PTK UMK. http://ptk.beit.co.id/

Bashir, I., \& Madhavaiah, C. (2015). Consumer attitude and behavioral intention towards Internet banking adoption in India. Journal of Indian Business Research, 7(1), 67-102. https://doi.org/10.1108/JIBR-02-2014-0 $\underline{013}$

Basioudis, I. G., Lange, de P., Suwardy, T., \& Wells, P. (2012). Accounting students' perceptions of a Learning Management System: An international comparison. Accounting Research Journal, 25(2), 72-86. https://doi.org/10.1108/MRR-09-2015-0216

Bhatiasevi, V. (2016). An extended UTAUT model to explain the adoption of mobile banking. Information Development, 32(4), 799-814. https://doi.org/10.1177/ $\underline{0266666915570764}$

Boonsiritomachai, W., \& Pitchayadejanant, K. (2017). Determinants affecting mobile banking adoption by generation Y based on the Unified Theory of Acceptance and Use of Technology Model modified by the Technology Acceptance Model concept. Kasetsart Journal of Social Sciences, 40(2), 1-10. https://doi.org/ 10.1016/j.kjss.2017.10.005

Carter, L., \& Bélanger, F. (2005). The utilization of egovernment services: Citizen trust, innovation and acceptance factors. Information Systems Journal, 15(1), 5-25. https://doi.org/10.1111/j.1365-2575.2005.0018 3.X

Cho, J. (2016). The impact of post-adoption beliefs on the continued use of health apps. International Journal of Medical Informatics, 87, 75-83. https://doi.o rg/10.1016/i.ijmedinf.2015.12.016
Davis, F. D. (1989). Perceived Usefulness, Perceived East of Use, and User Acceptance of Information Technology. MIS Quarterly, 13(3), 319-340. https://do i.org/10.1016/S0305-0483(98)00028-0

Faculty of Business and Economics UII. (2016). Prodi Akuntansi FE UII Terakreditasi ACCA. Fecon.Uii.Ac.Id. https://fecon.uii.ac.id/blog/2016/08/21/prodi-akuntan si-fe-uii-terakreditasi-acca/

Fai, K., Wang, X., Ng, L. T. W., \& Wong, Y. D. (2018). An investigation of customers ' intention to use selfcollection services for last-mile delivery. Transport Policy, 66, 1-8. https://doi.org/10.1016/j.tranpol.201 8.03.001

Fazli, M., Sam, M., Hoshino, Y., \& Tahir, N. H. (2012). The Adoption of Computerized Accounting System in Small Medium Enterprises in Melaka , Malaysia. International Journal of Business and Management, 7(18), 12-25. https://doi.org/10.5539/ijbm.v7n18p12

Fishbein, M., \& Ajzen, I. (1975). Belief, Attitude, Intention, and Behaviour: An Introduction to Theory and Research. Reading, MA: Addison-Wesley.

Gangwar, H., Date, H., \& Ramaswamy, R. (2015). Understanding determinants of cloud computing adoption using an integrated TAM-TOE model. Journal of Enterprise Information, 28(1), 107-130. http s://doi.org/10.1108/JEIM-08-2013-0065

Goh, T. T., Suki, N. M., \& Fam, K. (2014). Exploring a consumption value model for Islamic mobile banking adoption. Journal of Islamic Marketing, 5(3), 344-365. https://doi.org/10.1108/JIMA-08-2013-0056

Greenberg, R., Li, W., \& Wing, B. W.-O. (2012). The effect of trust in system reliability on the intention to adopt online accounting systems. International Journal of Accounting \& Information Management, 20(4), 363-376. https://doi.org/10.1108/18347641211 $\underline{272740}$

Hair, J. F., Hult, G. T. M., Ringle, C. M., \& Sarstedt, M. (2017). A Primer on Partial Least Squares Structural Equation Modeling ( PLS-SEM) (Second Edi). Sage Publications.

Hair, Money, A., Samouel, P., \& Page, M. (2007). Research methods for business. John Wiley and Sons.

Hassan, H. E., \& Wood, V. R. (2020). Does country culture influence consumers' perceptions toward mobile banking? A comparison between Egypt and the United States. Telematics and Informatics, 46, 1-13. https://doi.org/10.1016/j.tele.2019.101312

Ilias, A. (2013). Factor Affecting the Computerised Accounting System (CAS) Usage in Public Sector. Journal of Internet Banking and Commerce, 18(1), 1-29. Indonesian Government. (2008). Law Number 20 of 2008 regarding Micro, Small, and Medium Enterprises. 
Izuagbe, R., Hamzat, S. A., \& Joseph, E. I. (2016). Electronic Information Resources (EIR) Adoption in Private University Libraries: The Moderating Effect of Productivity and Relative Advantage on Perceived Usefulness. Journal of Information Science Theory and Practice, 4(1), 30-48. https://doi.org/10.1633/jistap.20 16.4.1.3

Jin, C. H. (2014). Adoption of e-book among college students: The perspective of an integrated TAM. Computers in Human Behavior, 41, 471-477. https://do i.org/10.1016/j.chb.2014.09.056

Kholid, M. N., Alvian, S., Yumewang, Y. K., \& Tumewang, Y. K. (2020). Understanding Determinants Mobile Accounting App Adoption By Micro, Small, and Medium Enterprise. Journal of Accounting and Strategic Finance, 3(1), 52-70. https://doi.org/10.3300 5/jasf.v3i1.74

Mahrizal, V. (2017). 80\% UMKM Belum Mampu Susun Laporan Keuangan. Tribunnews.Com. https://jogja.tri bunnews.com/2017/10/25/80-umkm-belum-mampu-s usun-laporan-keuangan

Malhotra, Y., \& Galletta, D. F. (1999). Extending the Technology Acceptance Model to account for social influence: Theoretical bases and empirical validation. Proceedings of the 32nd Hawaii International Conference on System Sciences, 1-11. https://doi.org/1 0.1109/hicss.1999.772658

Matell, M. S., \& Jacoby, J. (1972). Is there an optimal number of alternatives for likert scale items? Educational and Psychological Measurement, 56(6), 506-509. https://doi.org/10.1177/0013164471031003 $\underline{07}$

Melo, E., Llopis, J., Gascó, J., \& González, R. (2020). Integration of ICT into the higher education process: The case of Colombia. Journal of Small Business Strategy, 30(1), 58-67.

Min, S., Kam, K., So, F., \& Jeong, M. (2018). Consumer adoption of the Uber mobile application : Insights from diffusion of innovation theory and technology acceptance model Consumer adoption of the Uber mobile application: Insights from diffusion of. Journal of Travel \& Tourism Marketing, 36(7), 1-14. htt ps://doi.org/10.1080/10548408.2018.1507866

Morris, M. G., \& Venkatesh, V. (2000). Age Differences in Technology Adoption Decisions: Implications for A Changin Work Force. Personnel Psychology, 53, 375-403. https://doi.org/10.1111/j.1744-6570.2000.tb 00206.X

Morris, M. G., Venkatesh, V., \& Ackerman, P. L. (2005). Gender and age differences in employee decisions about new technology: An extension to the theory of planned behavior. IEEE Transactions on Engineering Management, 52(1), 69-84. https://doi.org/10.1109/T EM.2004.839967

Mutahar, A. M., Daud, N. M., Ramayah, T., Isaac, O., \& Aldholay, A. H. (2018). The effect of awareness and perceived risk on the technology acceptance model ( TAM ): mobile banking in Yemen. International Journal Services and Standards, 12(2), 180-204. http s://doi.org/10.1504/IJSS.2018.091840
Peregrina, Á. F. A., García, Á. H., \& Miguel, F. J. P. (2014). Behavioral intention, use behavior and the acceptance of electronic learning systems: Differences between higher education and lifelong learning. Computers in Human Behavior, 34, 301-314. https://doi.org/10.1016/j.chb.2013.10.035

Rafique, H., Almagrabi, A. O., Shamim, A., Anwar, F., \& Bashir, A. K. (2020). Investigating the Acceptance of Mobile Library Applications with an Extended Technology Acceptance Model (TAM). Computers and Education, 145, 1-13. https://doi.org/10.1016/j.compe du.2019.103732

Rahman, A. (2015). Toward a comprehensive conceptualization of digital divide and its impact on e-government system success. Advances in Business Marketing and Purchasing, 23A, 291-488. https://doi.o rg/10.1108/S1069-096420150000023003

Ramdhani, S., Istiqomah, E. nuzulia, \& Ardiyanti, G. K. (2012). The History of Yogyakarta, an Education City. International Proceedings of Economics Development and Research, 58(5). https://doi.org/10.7763/IPEDR

Reynolds, S., Cotrino, F., Ifedi, C., \& Donthu, N. (2020). An exploratory study of executive factors that lead to technology adoption in small businesses. Journal of Small Business Strategy, 30(2), 1-16.

Rogers, E. M. (2003). Diffussion of Innovation (5th ed.). Free Press.

Salloum, S. A., \& Shaalan, K. (2019). Adoption of EBook for University Students. Advances in Intelligent Systems and Computing, 481-494. https://doi.org/10.1 007/978-3-319-99010-1

Sang, S., Lee, J. D., \& Lee, J. (2009). E-government adoption in ASEAN: The case of Cambodia. Internet Research, 19(5), 517-534. https://doi.org/10.1108/106 $\underline{62240910998869}$

Schepers, J., \& Wetzels, M. (2007). A meta-analysis of the technology acceptance model: Investigating subjective norm and moderation effects. Information and Management, 44(1), 90-103. https://doi.org/10.10 16/j.im.2006.10.007

Schierz, G. P., Schilke, O., \& Wirtz, B. W. (2010). Electronic Commerce Research and Applications Understanding consumer acceptance of mobile payment services: An empirical analysis. Electronic Commerce Research and Applications, 9(3), 209-216. $\underline{\mathrm{h}}$ ttps://doi.org/10.1016/j.elerap.2009.07.005

Shaikh, I. M., Qureshi, M. A., Noordin, K., Shaikh, J. M., Khan, A., \& Shahbaz, M. S. (2020). Acceptance of Islamic financial technology (FinTech) banking services by Malaysian users: an extension of technology acceptance model. Foresight, 22(3), 367-383. https://doi.org/10.1108/FS-12-2019-0105

Sindo. (2018). Kampus Harus Punya Inkubator Bisnis. News.Okezone.Com. https://news.okezone.com/read/ 2018/12/17/65/1992318/kampus-harus-punya-inkuba tor-bisnis

Siyal, A. W., \& Ding, D. (2019). M-banking barriers in Pakistan: a customer perspective of adoption and continuity intention. Data Technologies and Applications, 53(1), 58-84. https://doi.org/10.1108/DT A-04-2018-0022 
Teo, T. (2010). A path analysis of pre-service teachers' attitudes to computer use: Applying and extending the technology acceptance model in an educational context. Interactive Learning Environments, 18(1), 65-79. https://doi.org/10.1080/10494820802231327

Thaker, M. A. M. T., Thaker, H. M. T., \& Pitchay, A. A. (2018). Modeling crowdfunders' behavioral intention to adopt the crowdfunding-waqf model (CWM) in Malaysia: The theory of the technology acceptance model. International Journal of Islamic and Middle Eastern Finance and Management, 11(2), 231-249. htt ps://doi.org/10.1108/IMEFM-06-2017-0157

Tribunella, T., \& Tribunella, H. (2016). Twenty Questions on the Sharing Economy and Mobile Accounting Apps. The CPA Journal. https://www.cpajournal.com/2016/0 5/17/twenty-questions-sharing-economy-mobile-acc ounting-apps/

Universitas Gadjah Mada. (2014). History of the Faculty Establishment. https://feb.ugm.ac.id/en/profile/histor y-of-the-establishment

Universitas Islam Indonesia. (2019). Empat Prodi UII Menerima Sertifikat Akreditasi AUN-QA. https://ww w.uii.ac.id/empat-prodi-uii-menerima-sertifikat-akre ditasi-aun-qa/

Universitas Muhammadiyah Yogyakarta. (2019). UMY Parcipates in the AUN-QA International Conference 2019 in the Philippines. https://iro.umy.ac.id/umy-par cipates-in-the-aun-qa-international-conference-201 9-in-the-philippines/

Urumsah, D. (2015). Factors Influencing Consumer to Use E-Service in Indonesian Ariline Companies. Advances in Business Marketing \& Purchasing, 23, 5-254. https://doi.org/10.1108/S1069-0964201500002 3B002

Utami, N. W. (2018). 5 Keuntungan Menggunakan Aplikasi atau Software Akuntansi. Jurnal.Id. https://ww w.jurnal.id/id/blog/2018-5-keuntungan-menggunaka n-aplikasi-atau-software-akuntansi/

Venkatesh, V., \& Davis, F. D. (2000). A theoretical extension of the technology acceptance model: Four longitudinal Studies. Management Science, 46(2), 186-205. https://doi.org/10.1287/mnsc.46.2.186.1192 $\underline{6}$

Wang, Y., Wang, S., Wang, J., Wei, J., \& Wang, C. (2020). An empirical study of consumers' intention to use ride-sharing services: using an extended technology acceptance model. Transportation, 47(1), 397-415. htt ps://doi.org/10.1007/s11116-018-9893-4
Watjatrakul, B. (2013). Intention to use a free voluntary service: The effects of social influence, knowledge and perceptions. Journal of Systems and Information Technology, 15(2), 202-220. https://doi.org/10.1108/1 $\underline{3287261311328903}$

Wu, H. Y., Lin, C. chun, Li, C. L., \& Lin, H. H. (2010). A Study of Bank Customers' Perceived Usefulness of Adopting Online Banking. Global Journal of Business Research, 4(3), 101-109.

Yalcin, M. E., \& Kutlu, B. (2019). Examination of students' acceptance of and intention to use learning management systems using extended TAM. British Journal of Educational Technology, 50(5), 1-19. http s://doi.org/10.1111/bjet.12798

Yang, Y., \& Wang, X. (2019). Modeling the intention to use machine translation for student translators: An extension of Technology Acceptance Model. Computers and Education, 133, 116-126. https://doi.or g/10.1016/j.compedu.2019.01.015

Yoon, H. Y. (2016). User Acceptance of Mobile Library Applications in Academic Libraries: An Application of the Technology Acceptance Model. Journal of Academic Librarianship, 42(6), 687-693. https://doi.or g/10.1016/j.acalib.2016.08.003

Youn, S. yi, \& Lee, K. H. (2019). Proposing value-based technology acceptance model: testing on paid mobile media service. Fashion and Textiles, 6(1), 1-16. http s://doi.org/10.1186/s40691-018-0163-z

Yuen, A., \& Ma, W. (2008). Exploring teacher acceptance of e-learning technology. Asia-Pacific Journal of Teacher Education, 36(3), 229-243. https://doi.org/1 $\underline{0.1080 / 13598660802232779}$

Yuen, Cai, L., Qi, G., \& Wang, X. (2020). Factors influencing autonomous vehicle adoption: an application of the technology acceptance model and innovation diffusion theory. Technology Analysis \& Strategic Management, 33(5), 1-15. https://doi.org/1 $\underline{0.1080 / 09537325.2020 .1826423}$

Zulaikha, M. (2017). Bekraf permudah pelaku UKM buat laporan keuangan dengan aplikasi akuntansi UKM. Berkaf.Go.Id. https://www.bekraf.go.id/berita/page/1 0/bekraf-permudah-pelaku-ukm-buat-laporan-keuan gan-dengan-aplikasi-akuntansi-ukm 